\title{
The electricity supply industry in the Democratic Republic of the Congo
}

\author{
J M Lukamba-Muhiya
}

\section{E Uken}

Both of the Energy Technology Unit, Cape Peninsula University of Technology, Cape Town, South Africa

\begin{abstract}
The electricity supply industry of the Democratic Republic of Congo is reviewed, from the formation of the Societé National d'Electricite (SNEL) in 1970 until today. The DRC government established a national utility, because electricity is a key element in the socio-economic development of a country. Due to the national monopoly of SNEL, hydropower plants could be constructed such as Inga1 and Inga2. They supply power to mining in the Katanga province, and to a steel company in Maluku, not far from Kinshasa. Currently, Inga1 and Inga 2 are not operating at full capacity. Many hydropower and thermal plants are located in different provinces and need to be refurbished to increase their capacity of electricity for the DRC. Due to technical problems, SNEL only generates $1150 \mathrm{MW}$. The electrification programme in urban and rural areas across the DRC caters for less than $10 \%$ of the 60 million inhabitants. In 1980, the government implemented a policy called Plan Directeur de SNEL for electrification, but the policies never reached their objectives. No Energy White Paper exists which outlines the entire policy framework for energy supply and demand. Power sector reform has also not been implemented in the electricity sector. This paper outlines future government options in the electricity sector. Accordingly, the Public Private Partnership model could play a major role in attracting private partners to invest in the electricity sector in order to have different hydropower and thermal plants refurbished.
\end{abstract}

Keywords: hydropower, Democratic Republic of Congo (DRC), electricity use, public private partnership

\section{Introduction}

In most African countries people still use wood, paraffin, candles and other fuel for lighting, heating and cooking. Despite this, the continent has abundant potential sources of energy, especially solar, wind, thermal and hydroelectric power. On 16 May 1970, the Zairian government, under the Mobutu regime, signed a government decree, number 70/033, for the establishment of SNEL as a Public Enterprise Company. It is a national utility with characteristics of an industrial and commercial public enterprise. On 5 May 1978, the Zairian government signed another decree, No 78/196. After the implementation of the new decree, SNEL took over the generation, transmission and distribution of electricity in the DRC. The company is run by a board of directors, the management committee, and 'le College des Commissaires aux Comptes' which manages the national utility (SNEL, 2005:4). The establishment of SNEL in 1970 was subjected to the Royal Decree of 9 November 1956, including a set of regulations and general Block Notes, determining applicable principles and concessions for public distribution of electric energy.

Current electricity capacity in the DRC is 1150 Megawatts (MW) per year, consisting of $98 \%$ hydropower and $2 \%$ thermal plants. The potential hydropower capacity of the DRC is estimated to be as high as about $100000 \mathrm{MW}$, of which the Inga Dam constitutes $44 \%$ of the 'Societe National d'Electricité' (SNEL, 2000:3). If exploited to its fullest capacity, the Inga Dam could be one of the biggest hydropower stations in the world. This would increase the DRC's ability to electrify the entire country and also to export more electricity to other African states. The internal generation, transmission, and distribution as well as the exportation of electricity from the DRC is the responsibility of SNEL.

Since 1970, when SNEL was established, the government made the following contribution at var- 
ious levels:

- New hydropower plants and thermal plants (for example, Inga 1, Inga 2, and Hydropower of Mobayi).

- New transmission and distribution lines in different provinces.

- Nationalisation of private electricity companies in 1972 and 1974.

- Transfer of all thermal plants from Regideso (another public company that distributes water in the country) to SNEL in 1979 (SNEL, 2005:4). All these transfers of infrastructure by the government do not give the national utility financial support. Since that time the national utility has experienced financial difficulties.

The national utility generates and sells electric energy across the country. In addition to that, SNEL also purchases electricity from independent power producers such as some mining companies, which have their own power plants. The national utility has a national monopoly in terms of generation, transmission and distribution of electricity in the $\mathrm{DRC}$, including exporting electricity to neighbouring countries.

This paper reviews the current situation of Electricity Supply Industry (ESI) in the DRC after 45 years of its independence, highlighting its export potential of electricity to the Southern African Development Community (SADC) and other countries in Africa. Access to electricity in the DRC is still a luxury for many households. Although the DRC government has been in power since 1960, it still does not have an effective energy policy in place to promote an electrification programme in urban and rural areas. The policies formulated during the rule of the previous government under Mobutu could not be implemented, because of general mismanagement. Access to electrification today is enjoyed by less than $10 \%$ of the population. This paper will also analyse what the impact of a public private partnership (PPP) could be after the elections, which were to be held in June this year.

\section{Socio-economic background of the DRC}

The Democratic Republic of the Congo, formerly known as Zaire, is a nation in which monumental, political and administrative problems have occurred since independence. The population of the DRC rose to 60 million inhabitants according to the 2005 census. It borders Angola in the Southwest and west, with Cabinda and the Republic of Congo in the West, Central African Republic and Sudan in the North, with Uganda, Rwanda, Burundi and Tanzania in the East, and with the Republic of Zambia in the Southeast (Columbia encyclopaedia, 2002:1). The country consists of 11 provinces: Bandundu, Bas Congo, Equateur, Kasai-Occidental, Kasai-Oriental, Katanga, Maniema, Nord-Kivu, Sud-
Kivu and Province Oriental and Kinshasa, which is the capital, with a population of 8 million inhabitants.

The DRC is potentially the wealthiest country in Africa, but stands today as an impoverished development tragedy. Gifted with fabulous natural resources, including copper, cobalt, gold, silver, tin, fertile soil and bounteous waterfalls, the DRC has woefully failed to meet its promise. According to the Columbia encyclopaedia (2002:2) mining is centred in Katanga province, which provides copper, cobalt, zinc, manganese, uranium, cassiterite (tin ore), coal, gold, and silver. Diamonds are mined in the Kasai and Oriental provinces. Major deposits of petroleum were discovered offshore, near the mouth of the Congo River. Almost $75 \%$ of the DRC is covered with forest, and a considerable amount of ebony and teak are produced annually, as well as less valuable types of wood.

From an economic point of view, Kinshasa and Lubumbashi are the most industrial cities of the country. Manufacturing includes processed copper, zinc, and cassiterite; refined petroleum, basic consumer goods such as processed food, beverages, clothing, footwear, and cement. The numerous rivers of the Congo give an immense potential for generating electricity, a small but significant percentage of which has been realized. The important hydroelectric facilities are situated in Katanga and produce electricity for the mining industry. In addition, there is another big project at Inga, on the Congo River, in the Bas Congo province.

\section{Historical background of electricity supply in the DRC}

Before the government established SNEL in 1970, another public Enterprise Company called Regideso controlled the Electricity Supply Industry (ESI) from 1960 to 1972 . Today Regideso's principal work is to connect and distribute water all over the country. Beside Regideso, six other private companies generated and distributed electricity in the country, namely:

- Comectrick

- Forces de Lest

- Forces du Bas-Congo

- Sogefor

- Sogelec, and

- Cogelin

In 1970, SNEL became a national utility with the mandate to generate, transmit and distribute electricity across the country. Four years later the government decided to implement a new decree, No 74/012 of 14 May 1974, allowing SNEL to take over all six private companies, which had an obligation to generate and distribute electricity in the other provinces. This decision, gave SNEL a national monopoly as the ESI (SNEL, 2000:7). The Regideso returned its hydroelectric plants and ther- 
mal plants to SNEL only in 1979. Therefore, Regideso no longer controls power plants in the DRC.

The implementation of the SNEL policy is to ensure that the state controls the generation, transmission and distribution sector. Electricity is considered to be a main factor for the economic and social development of the country. There are a few independent power producers around the country. Most of these are mining companies, although some other companies also have their own thermal generators to supply electricity for their own use. SNEL also has the option to buy electricity from private companies. Figure 1 shows all the sites for hydropower and thermal plants across the country.

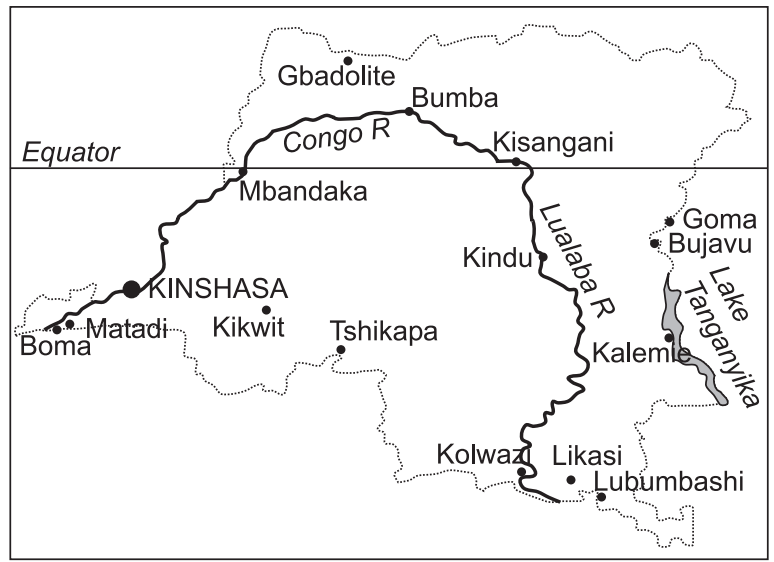

\section{Figure 1: Hydropower potential across the country}

Source: (SNEL 2000)

Figure 1 shows different provinces with potential for the construction of hydropower across the country. The River Congo (Lualaba) starts in the south of the $\mathrm{DRC}$, ending at the mouth in Boma, not far from where the Inga hydropower is located.

The different types of energy carriers used in the DRC are also considered later, suggesting some solutions which the DRC government could consider to ensure energy security in future. The ESI in the $\mathrm{DRC}$ is reviewed under the following headings:

- Electricity capacity in the DRC

- Electricity supply industry, and

- Future governance option

\section{Electricity capacity of the DRC}

The total capacity of electricity generated with all hydropower and thermal plants fully operational is 2505 MW. According to SNEL, Plan de Sauvetage et de Redressement (PSR, 2005:15), the technical problems in different hydropower and thermal plants limit SNEL to currently only generate 1150 MW respectively, is due to a lack of maintenance and spare parts. SNEL has a strategic programme to rehabilitate different hydropower plants, starting with Inga 1, Inga 2 and Zongo, located in the province of Bas Congo, Nseke and Mwadingusha in the Katanga province. Only a few turbines are operating in each hydropower plant. Figure 2 represents different plants that SNEL is rehabilitating since last year. The capacity in terms of MW of all these different hydropower plants is also shown in Table 1.

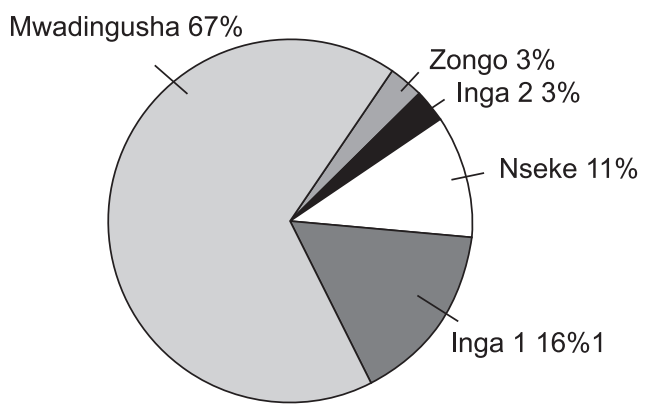

Figure 2: Hydropower plants under
rehabilitation

The rehabilitation of these plants will increase the capacity in terms of electricity generation. Beside these hydropower plants, there are also other hydropower and thermal plants that need refurbishment. There is the possibility of upgrading some plants, but it is a problem for the government to find partners to invest. The rehabilitation of the five hydropower plants could assist SNEL recover 1416 MW estimated capacity from rehabilitated hydropower plants across the country. Table 1 below represents all hydropower plants for SNEL and different mining companies across the country. The dates when the SNEL plants were commissioned, are given in brackets.

According to Table 1, the DRC has at least 27 hydropower stations across the country. Some of the plants are not working to their full capacity. Therefore, there are plants that need to be refurbished scattered across the country. The large number of existing hydropower stations and the potential assets should allow the government to implement a successful policy for improving electrification and offering far greater access within the country.

Apart from the hydropower, there are also a number of thermal power plants around the country without an interconnection or grid connection with transmission lines coming from Inga 1 and Inga 2. Some of these thermal plants are located in the north and eastern part of the DRC. These plants are not in operation everyday, because of the lack of spare parts and fuel shortage in certain areas. The five years of civil war exacerbated also this situation. Plan de Sauvetage et de Redressement (2005) reports that, it is the intention to change this situation in 2006. For example, in the Equatorial 
Table 1: Hydropower capacity in the DRC in 2000

Source: SNEL Annual Report (2000:19)

\begin{tabular}{|c|c|c|}
\hline $\begin{array}{l}\text { Power plant \& year } \\
\text { of commissioning } \\
\text { by province }\end{array}$ & $\begin{array}{c}\text { Ownership } \\
\text { (SNEL or mining } \\
\text { company) }\end{array}$ & $\begin{array}{c}\text { Installed } \\
\text { Capacity } \\
(M W)\end{array}$ \\
\hline \multicolumn{3}{|l|}{ Bas Congo } \\
\hline Inga 1 (1972-74) & SNEL & 351 \\
\hline Inga2 (1981-82) & SNEL & 1424 \\
\hline Zongo (1955-65) & SNEL & 75 \\
\hline Sanga (1932-49) & SNEL & 12 \\
\hline Mpozo (1934) & SNEL & 2.21 \\
\hline \multicolumn{3}{|l|}{ Katanga } \\
\hline Mwadingusha (1929-54) & SNEL & 68 \\
\hline Koni (1950 & SNEL & 42.12 \\
\hline Nseke \& Nzilo (1953-57) & SNEL & 356.40 \\
\hline Kyimbi (1959) & SNEL & 17.20 \\
\hline Kilubi(1954) & SNEL & 9.9 \\
\hline \multicolumn{3}{|l|}{ Kivu } \\
\hline Ruzizi 1 (1958-1972) & SNEL & 28.2 \\
\hline Ruzizi 2 (1989) & SNEL & 26.6 \\
\hline \multicolumn{3}{|l|}{ Kasai occidental } \\
\hline Lungudi (1949) & SNEL & 1.6 \\
\hline \multicolumn{3}{|l|}{ Province Oriental } \\
\hline Tshopo (155-1974) & SNEL & 18.8 \\
\hline \multicolumn{3}{|l|}{ Equateur } \\
\hline Mobayi (1988-1989) & SNEL & 11.40 \\
\hline Budana & Kilomoto & 13.8 \\
\hline Nzoro & Kilomoto & 1.4 \\
\hline Soleniama1 & Kilomoto & 13.5 \\
\hline Soleniama2 & Kilomoto & 1.6 \\
\hline Ambwe/Kailo & Sominki & 2.2 \\
\hline Belia & Sominki & 2.2 \\
\hline Mangembe & Sominki & 1.8 \\
\hline Lulingu & Sominki & 0.7 \\
\hline Lutshurukuru & Sominki & 5.1 \\
\hline Moga & Sominki & 0.4 \\
\hline Tshala\&Lubilanji1 & Miba & 8.6 \\
\hline Piana Mwanga & Congo Etain & 29 \\
\hline Total & & 2524.13 \\
\hline
\end{tabular}

province a lack of fuel can cause a power outage for an entire month. Table 2 shows the status of thermal power plants per province starting from 1980 compared with those of 2000 , to indicate broad trends.

During the civil war from 1998 to 2003 , some of these thermal power plants could not run properly, because of the lack of fuel and engine parts from the SNEL head office in Kinshasa. According to a
Table 2: Thermal power plants in the DRC in 1980 and 2000

Source: SNEL Annual Report (2000:21)

\begin{tabular}{lcc|cc}
\hline & \multicolumn{2}{c|}{1980} & \multicolumn{2}{c}{2000} \\
\hline $\begin{array}{l}\text { Site of plant } \\
\text { by province }\end{array}$ & $\begin{array}{c}\text { No. of } \\
\text { plants }\end{array}$ & $\begin{array}{c}\text { Capa- } \\
\text { city }\end{array}$ & $\begin{array}{l}\text { No. of } \\
\text { plants }\end{array}$ & $\begin{array}{c}\text { Capacity \& } \\
\text { type of plant }\end{array}$ \\
\hline Bas Congo & & & & \\
\hline 1. Muanda & 2 & 2.2 & 3 & 1.6 (Gas plant) \\
\hline 2. Lukala & 2 & 0.3 & 1 & 0.3 \\
\hline 3. Tshela & 2 & 0.4 & 2 & 0.4 \\
\hline 4. Lemba & 1 & 1.3 & & Grid* \\
\hline 5. Bomba & 5 & 4.5 & & Grid* \\
\hline Bandundu & & & &
\end{tabular}

Bandundu

\begin{tabular}{lcc|cc}
\hline 6. Kikwit & 4 & 1 & 2 & 0.9 \\
\hline 7. Inongo & 2 & 0.3 & 1 & 0.2 \\
\hline 8. Bandundu & 2 & 0.8 & & Grid* \\
\hline
\end{tabular}

Kasai Occidental

\begin{tabular}{lll|ll}
\hline 9. Kananga & 4 & 4.2 & 3 & 2.7 \\
\hline 10. Mweka & 2 & 0.4 & 2 & 0.4 \\
\hline Kasai Oriental & & & &
\end{tabular}

\begin{tabular}{lcc|cc}
\hline 11. Mbuji Mayi & 4 & 12.9 & 1 & Grid* $^{*}$ \\
\hline 12. Lusambo & 2 & 0.6 & 2 & 0.6 \\
\hline 13. Kabinda & 2 & 0.6 & 2 & 0.6 \\
\hline Equateur & & & &
\end{tabular}

Equateur

\begin{tabular}{lll|ll}
\hline 14. Mbandaka & 4 & 4.3 & 3 & 2.3 \\
\hline 15. Basankusu & 2 & 0.3 & 2 & 0.3 \\
\hline 16. Boende & 2 & 0.4 & 2 & 0.4
\end{tabular}

\begin{tabular}{lll|ll}
\hline 16. Boende & 2 & 0.4 & 2 & 0.4 \\
\hline 17. Bumba & 3 & 0.8 & 1 & 0.4
\end{tabular}

\begin{tabular}{lll|ll}
\hline 18. Lisala & 6 & 1.4 & 6 & 1.4 \\
\hline 19. Gemena & 4 & 1.2 & 4 & 1.2 \\
\hline 20. Libenge & 2 & 0.8 & 2 & 0.8 \\
\hline 21. Zongo & 1 & 0.3 & 1 & Grid*
\end{tabular}

\begin{tabular}{lcc|cc}
\hline 22.Gbadolite & 4 & 1.2 & - & - \\
\hline Maniema & & & & \\
\hline 23. Kindu & 3 & 1.7 & 1 & 0.6 \\
\hline 24. Kasongo & 2 & 0.6 & 2 & 0.6
\end{tabular}

\begin{tabular}{lcc|cc}
\hline 24. Kasongo & 2 & 0.6 & 2 & 0.6 \\
\hline Katanga & & & & \\
\hline 25. Kabalo & 2 & 0.4 & 2 & 0.4 \\
\hline 26. Kongolo & 3 & 0.9 & 1 & 0.3 \\
\hline 27. Kamina & 3 & 0.8 & - & Grid* \\
\hline 28. Kaniama & 3 & 0.5 & 3 & 0.5 \\
\hline 29. Kasenga & 2 & 0.2 & - & Grid* \\
\hline Nord Kivu & & & & \\
\hline 30. Goma & 4 & 2.4 & - & Grid* \\
\hline 31. Butembo & 1 & 0.3 & 1 & 0.3 not running \\
\hline 32. Kisangani & 4 & 12.8 & 4 & 12.8 \\
\hline 33. Buta & 3 & 0.6 & 3 & 0.6 \\
\hline Total & $\mathbf{9 2}$ & $\mathbf{6 1 . 0 3} \mathbf{M w}$ & $\mathbf{5 4}$ & $\mathbf{3 0 . 8} \mathbf{M w}$ \\
\hline
\end{tabular}

* Connected to national grid 
senior official of SNEL (2005), few thermal plants in different provinces are connected to the national transmission lines. The major role for all these plants is to distribute electricity locally in the different provinces. Most of these plants will not operate again as thermal plants in future. Some of the thermal plants have, however, become operational again after the peace process.

\section{The electricity supply industry}

The working structure of the ESI can be divided, along operational lines, into three sectors: generation, transmission and distribution. The structure of generation of electricity starts from Hydropower, Thermal and Gas plants. The transmission sector is built up with high voltage lines starting from the generation to the distribution sector. The national utility transmission lines have been divided into six categories in terms of capacity. In Table 3, different transmission lines in kilowatt and kilometres within the DRC electricity sector are shown. The longest national grid in the DRC was inaugurated in 1982 when Inga 2 became operational. That transmission line is called Inga-Kolwezi. The same transmission line connects the DRC to Zambia and other countries in SADC.

Each province within the country has one or two hydropower, or thermal plants, which generate electricity. Large capacities of electricity generation are located in the Katanga and Bas Congo provinces.

According to the financial indicator of SNEL 2005 , the performance of the national utility is not good. The sales of electricity in MW within the country are low. In 2003 SNEL sold $64 \%$ of electricity and in 2004 the utility sold $63 \%$, due to a poor electrification programme for the country. Very low numbers of the population have access to electricity. Only 276431 domestic customers in Kinshasa, a city of 8 million inhabitants, have access to electricity. There is also a large number of informal customers in Kinshasa and elsewhere in the country, which SNEL still found difficulty to capture on its database.
According to SNEL's Plan de Sauvetage et de Redressement (2005:10), less than 10\% of the population has access to electricity. There are also big losses of electricity on the distribution side. SNEL recorded that more than $30 \%$ of electricity has been lost during the past four years. For example, in 2004 the companies recorded a loss of $41 \%$, and in 2003 a loss of $37.4 \%$ (SNEL, 2005:19). There is a possibility to re-establish the national DRC utility by meeting the technical and commercial requirements of international standards. All this should be done with a responsible government and to avoid political interference. In Figure 3, the structure of ESI in the $\mathrm{DRC}$ is presented.

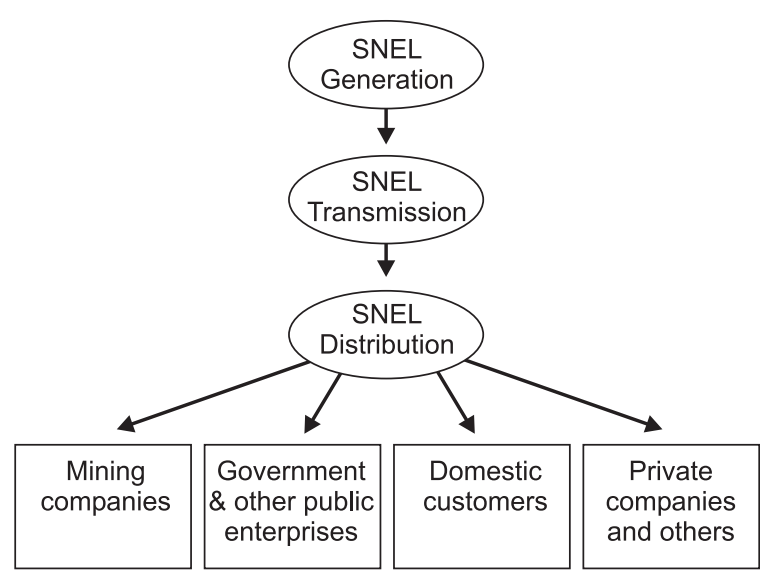

Figure 3: Structure of the ESI in the DRC

According to the International Energy Agency (IEA, 1994:24), vertical integration describes the relationship or linkage between the main functional activities within the electricity supply chain. It could be argued that SNEL is having a vertical integration on electricity sector within the country. The distribution of electricity in the country is problematic and power outages happen frequently. This situation of having poor electricity services in the DRC has impacted negatively on many households and on the economy generally. The consequence of not having reliable sources of electricity, in some urban

Table 3: Transmission lines in kilometres, in terms of high voltage values Source: SNEL (2000: 24)

\begin{tabular}{lccccccc}
\hline Location & $500 K V$ & $220 K V$ & $132 K V$ & $120 K V$ & $70 K V$ & $55 / 50 K V$ & Total in $\mathrm{km}$ \\
\hline Bas-Congo & & 216.6 & 185.3 & & 164.5 & & 611.4 \\
\hline Kinshasa & 123.6 & & & 80 & & 203.6 \\
\hline Bandundu & 264 & & & & 264 & \\
\hline Equateur & & 22.5 & & & 22.5 & \\
\hline Kivu & & & & 260 & & 260 \\
\hline Katanga & & 834.1 & 120 & 1198.8 & 70 & 188.8 & 2411.7 \\
\hline Inga-Kolwezi & 1774 & & & & & 1774 & \\
\hline Total in Km & $\mathbf{1 7 7 4}$ & $\mathbf{1 4 8 3 . 3}$ & $\mathbf{3 2 7 . 8}$ & $\mathbf{1 1 9 8 . 8}$ & $\mathbf{5 7 4 . 5}$ & & $\mathbf{5 5 4 7 . 2}$ \\
\hline
\end{tabular}


areas, contributes to the closure of many businesses, forcing them to move to places where electricity supply is reliable.

\section{Future governance options}

The government still has to implement an electrification programme across the country to boost the number of domestic customers who have access to electricity. This policy was approved by Mobutu's regime two decades ago. Currently, Plan Directeur de SNEL for urban and rural electrification is on hold. There are few places in Katanga province where electrification for rural areas is taking place. Hence, the major programme for urban and rural electrification programme is still lagging behind for over two decades. Discussions are taking place between the government and SNEL to carry out the programme of electrification after the presidential election, which will be held this year.

\subsection{Major consumers of electricity}

There are two major consumers of electricity in the country: the DRC's government buildings, and some public enterprise companies, like the mining sector. These two consumers use $50 \%$ of the electricity produced in the DRC each year (SNEL, 2005:5). The remaining companies are private and other businesses around the country.

The domestic consumption is very low because of the lack of electrification programmes. The remaining electricity generated is being exported to countries that have already signed a bilateral agreement with the national utility. These include Angola, Congo Brazzaville, Central Africa Republic, Burundi, Rwanda, Zimbabwe and South Africa. In Figure 4 the electricity usage in the DRC is shown. It will change with time, depending on demand and the accessibility of electricity by different sectors.

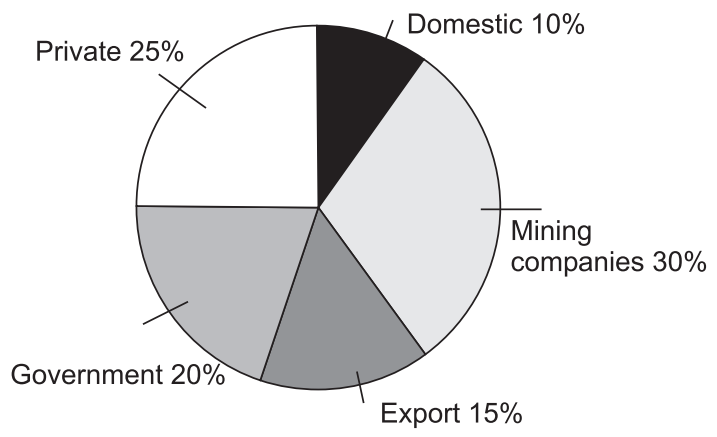

Figure 4: Profile of electricity usage in the DRC

\subsection{Governance structure}

The electricity sector of the DRC holds the key to social and economic development of the country. Government has controlled this sector since independence. The national utility is under the direct control of the Ministry of Energy, and all government decisions relating to the electricity supply industry are implemented by the Ministry of Energy. The Ministry of Public Enterprise controls the financial part of SNEL. Currently, there is no Energy White Paper from the transitional government which should underline the policy of the government. Most of the policies involved in the electricity sector are from the previous regime under Mobutu. There is a possibility of a new democratic government, after the election in June 2006, with a possibility of new policies and strategies for the country.

The ESI regulation generally involves a degree of public price control, and normally, it extends to control over other areas, such as levels of service, and planning and investment decisions (Steyn, 1994: 22). At present, in the case of the DRC government, there is no regulatory body for the electricity sector, as in the case of the National Energy Regulator of South Africa (NERSA). A commission has taken most of the decisions regarding electricity tariffs; the level of service delivery and other matters.

The International Energy Agency (1994:42) declared that the government has tended to reinforce the monopoly position of utilities by passing legislation, which granted the companies special or exclusive rights. SNEL, as national utility, has supplied electricity for over 35 years without a regulatory body. It would be important to assist the local utility to become more efficient, and evaluate the electricity tariff every year. However, the DRC government is the only agency which intervenes directly in any policy making for the transformation of SNEL. There is a need to have an independent body to start regulating the electricity tariffs and to suggest to the government and SNEL the way forward to improve the service levels of the national utility.

\subsection{Public private partnership (PPP)}

\subsubsection{Background}

After reviewing the ESI of the DRC, it became evident that a real need exists for the DRC government to take an initiative to apply a PPP model in the electricity sector. According to the European Union, (EU) Green Paper (2004:3), the term of PPP is not defined at the community level. In general, this term refers to a form of co-operation between public authorities and the world of business, which aims to ensure effective funding, construction, renovation, management or maintenance of an infrastructure or the provision of a service.

Furthermore, reviewing the ESI of the DRC, there are different possibilities to apply PPP model with many hydropower and thermal plants located in different provinces across the country. Most of the hydropower under SNEL supervision has over 25 years of operation, and some of them are not 
operating to their full capacity. The International Monetary Fund, World Bank and Belgian government granted a loan of over $\$ 200$ million to rehabilitate some hydropower and thermal plants.

Another option is getting big loans from financial institutions, as the Congolese government is trying the PPP model to rehabilitate the electricity sector. According to SEFI (2001:12) PPP can be used for new projects and rehabilitation or maintenance projects. When one analyses the DRC electricity sector, the introduction of a PPP model appears very feasible, because there is a need for SNEL to rehabilitate most of the hydropower across the country. SNEL does not have sufficient funds to rehabilitate all its plants. A relationship with a private partner would be the best way for the government to come out of its financial difficulties.

\subsubsection{Model for PPP}

There are different types of PPP models that the DRC government could consider for the rehabilitation of different hydropower and thermal plants. It would be good for the government to realise that PPP does not mean privatisation of government assets. Instead, PPP can sustain the government to upgrade or rehabilitate some of the power plants. Seader (2004:4) argues that, instead, partnership refers to an entire spectrum of relationships where private sector resources are used in the delivery of services or facilities for public use. The private sector could support the national utility to provide one or more of the following:

- Designing a new project

- Financing

- Project initiation and planning

- Construction

- Ownership

- Operation, and

- Revenue collection.

The PPP model falls into two categories: the first is the establishment of a new project and the second aims at refurbishment of existing facilities.

\section{3.3 New projects}

There are different models for new projects:

- Build-transfer (BT)

- Build-lease-transfer (BLT)

- Build-operate-transfer(BOT)

- Build-own-operate-transfer(BOOT)

The recommended approach for the government is to choose which model best suits the rehabilitation of electricity power plants. For example, the BOT could be appropriate for a plant rehabilitation and new construction. This model of PPP offers the government the possibility to convert development and initial operation from a public sector project to a private one.

Seader (2004:5) states that the private sector contractor or consortium of contractors finances the project, accomplishes the construction, and operates the new facility for some specified length of time, after which it is expected to transfer ownership to the government, mostly at no cost. The prospective transfer to the host government happens immediately it can retain control of the asset. The DRC's government could use this BOT model to build the third phase of Inga. The BOT model is especially suitable for different governments because it offer the host country many options such as:

- The capacity to reduce capital costs for a particular project at a time when it intends to provide funds for another project.

- The chance to encourage outside investment and introduce new or improved technology (Seader, 2004:5).

Furthermore, this model works as well for rehabilitation of power plants or expansion of an existing facility, sometimes called its Rehabilitate-OperateTransfer (ROT). There are so many hydropower and thermal plants within the DRC that need a complete rehabilitation. If government could apply this type of PPP model it would enable SNEL to increase power generation across the country. In addition, according to Elizabeth (1999:3) this model is being used in different developing countries to build new infrastructure. There are a few examples in some of the French speaking countries in Sub Saharan Africa.

BOT is not the best model for all PPP models because, for example, it focuses only on one facility, which limits the private sector actor's ability to help optimise system wide resources or efficiencies (Elizabeth, at al: 1999). Nevertheless, this model provides a platform for increasing local capacity, and to operate infrastructure facilities. This type of model also provides an incentive to be efficient, since companies have to perform well in order to win the contracts.

In terms of applicability of PPP in the electricity sector, the DRC government has already allowed two local companies, Electricity du Congo (EDC) and Societé d'Electricité de Nord Kivu (SONEKI), to run two hydropower plants. According to Kalala (2005), the first project is located in Kasai Occidental, and the EDC is rehabilitating the hydropower of Lungudi, which was commissioned in 1949 with a capacity of $1.6 \mathrm{MW}$ (Ministry of Energy, 2005). The objective of this PPP model is to rehabilitate the hydropower plants and also to electrify the city of Kananga. SENOKI, located in Butembo in North of Kivu province, runs the second project. The capacity of the plants is $1.2 \mathrm{MW}$. The transitional government gave the two companies a 25year period to run the plants with a possibility to renew the project. Learning from the local private company's experience, there is a possibility for the government to extend this kind of project for the big hydropower plants in different provinces. 


\subsubsection{Existing facilities}

In the second type of appropriate model, the infrastructure is already in place, but the government is looking for a partner to mainly manage the existing facilities. The presentation of this model is to review the SNEL situation and to see which model can be used to solve some of the problems the national utility is facing.

One example could be a Service contract. This model could solve the problem concerning the billing and collection in order to increase the revenue for SNEL across the country. In service contracts, the government or the national utility maintains the greatest degree of control over its services and facilities. The private company has all its terms of service spelt out in the service contract.

According to Seader (2004:6), in service contracting, or contracting out, the government contracts with a private company to supply functional responsibilities that the public sector previously performed, such as billing and collection. In this kind of contract, the responsibility lies with the government to choose the best company to do the job. SNEL and the DRC government never used this kind of model for the electricity sector across the country. It is the responsibility of the government to check the performance of SNEL and to see if such a model would be efficient and work effective for the whole country, especially in rural areas.

\section{Conclusion}

Most observes seems to agree that the performance of SNEL during its 35 years of existence, calls for a real change. This means that SNEL should implement corporate governance within the structure of the utility. There is a need for power sector reform to help SNEL to rehabilitate most of its plants located in different provinces. There is a need for central government to avoid political interference in the running of the national utility.

Corruption within SNEL could also cause the company to collapse. A possible new government after the presidential election needs to encourage a better transformation in all the structures of the national utility. An aggressive electrification programme should be a priority for the government and SNEL, aimed at offering access to electricity to many more domestic customers in urban and rural areas.

\section{References}

Columbia Encyclopaedia (2001). Bibliographic Record. Congo, Democratic Republic. Columbia University Press.

Elizabeth, B, Peter, G and Brad, G (1999). Public Private Co-operation in the delivery of urban infrastructure service options and issues. UNDP, New York.
European Union (2004). Green Paper in Energy. www.eea.eu.int [14 October 2005]

International Energy Agency (1994). Electricity Supply Industry. Structure, ownership and regulation in OECD countries. Paris.

Kalala, T 2005. Interview with deputy director of Electricity (2005). Department of Energy (DRC Government). Kinshasa, Gombe.

Seader, D.L (2004). The United States experience with outsourcing. Privatisation and Public Private

Partnerships. USA.

SEFI (2001). For new PPP in infrastructure and public facilities. Association of French International Contractors. Paris

Societé Nationale d'Electricité (2000). Trente ans de vie de SNEL 1970-2000. Kinshasa, Gombe.

Societé National d'Electricité (2005). Plan de Sauvetage et de Redressement. Kinshasa, Gombe.

Societé National d'Electricité (2005). Plan de Sauvetage et de Redressement de l'Entreprise 'Annexes'. Kinshasa, Gombe.

Steyn, G (1994). Restructuring the South African Electricity Supply Industry. EDRC, University of Cape Town.

Received 16 August 2005; revised 9 May 2006 